\title{
Is subchondral bone the crucial point for the pathogenesis and the treatment of osteoarthritis?
}

\author{
Subkondral kemik osteoartirit patogenezi ve tedavisi için en önemli nokta mıdır? \\ O. Şahap Atik, M.D.
}

Department of Orthopedics and Traumatology, Medical Faculty of Gazi University, Ankara, Turkey

Osteoarthritis results from a complex system of interacting mechanical, biological, biochemical, molecular and enzymatic factors. ${ }^{[1,2]}$ There is strong evidence that bone marrow lesions and bone cysts have an important role in the pathogenesis of knee osteoarthritis. ${ }^{[3]}$ Bone marrow lesions including dense bone islands may cause decrease of the elasticity in subchondral bone. ${ }^{[4]}$ Eventually, they may result in osteoarthritis, playing a key role in the initiation and progression of cartilage erosion.

Loss of osteochondral integrity removes the barrier between intra-articular and subchondral compartments, exposing subchondral bone and its nerves to abnormal chemical and biomechanical influence. ${ }^{[5]}$

Sensitive and accurate methods, to assess structural changes at the onset of osteoarthritis such as high-resolution magnetic resonance imaging are therefore crucial in the discovery of the key players in the initiation and progression of the disease, differentiation of the disease subgroups, and assessment of the therapeutic efficacy of novel treatments. ${ }^{[1,6]}$

Increased bone turnover have been detected in the early evolution of some forms of osteoarthritis, like in osteoporosis, and recent findings suggest that some drugs may be useful in treating both processes simultaneously. ${ }^{[5,7]}$

It has long been considered that osteoarthritis is a disease of articular cartilage, whereas, with the introduction of the recent data, subchondral bone is attracting more attention.

\section{REFERENCES}

1. Martel-Pelletier J, Pelletier JP. Is osteoarthritis a disease involving only cartilage or other articular tissues? Eklem Hastalik Cerrahisi 2010;21:2-14.

2. Sahap Atik O. Leukotriene B4 and prostaglandin E2-like activity in synovial fluid in osteoarthritis. Prostaglandins Leukot Essent Fatty Acids 1990;39:253-4.

3. Raynauld JP, Martel-Pelletier J, Berthiaume MJ, Abram F, Choquette D, Haraoui B, et al. Correlation between bone lesion changes and cartilage volume loss in patients with osteoarthritis of the knee as assessed by quantitative magnetic resonance imaging over a 24-month period. Ann Rheum Dis 2008;67:683-8.

4. Atik OŞ, Tokgöz N. Do periarticular dense bone islands cause cartilage destruction? Eklem Hastalik Cerrahisi 2013;24:39-40.

5. SuriS, WalshDA. Osteochondral alterations in osteoarthritis. Bone 2012;51:204-11.

6. Bijlsma JW, Berenbaum F, Lafeber FP. Osteoarthritis: an update with relevance for clinical practice. Lancet 2011;377:2115-26.

7. Castañeda S, Roman-Blas JA, Largo R, Herrero-Beaumont G. Subchondral bone as a key target for osteoarthritis treatment. Biochem Pharmacol 2012;83:315-23.

\footnotetext{
- Correspondence: O. Şahap Atik, M.D. Gazi Üniversitesi Tıp Fakültesi Ortopedi ve Travmatoloji Anabilim Dalı, 06500 Beşevler, Ankara, Turkey. Tel: +90 312 - 2025528 Fax: +90 312 - 2129008 e-mail: satikmd@gmail.com
} 